\title{
Human Rights In An Unwritten Constitution
}

\author{
The Rt. Hon. Lord Scarman*
}

In this paper I shall endeavour to answer two questions. Can we use our constitution to establish legal safeguards which will protect our basic rights and liberties against an irresponsible or negligent or tyrannical legislature? By "legal safeguards" I mean the protection of the law as distinct from the protection provided by political and social pressures upon Parliament. If we can establish an acceptable degree of legal protection, is it really needed? The first is a constitutional question: the second goes to the merits, or the heart of the matter. The second question could be put more tendentiously in these terms: is the protection of human rights available now in the United Kingdom - be it legal, political, social or a mix of the three, a sufficient safeguard for rights which we call "human" because we believe them to be so basic that they should be, in the great Jeffersonian phrase, "unalienable"?

\section{The Constitutional Question}

A determined effort was made in the Parliamentary sessions 1985/86 and 1986/87 to pass a bill to incorporate into British law the human rights and fundamental freedoms protected by the European Convention for the Protection of Human Rights and Fundamental Freedoms. ${ }^{2}$ Had such a bill become an Act of Parliament, anybody within the United Kingdom could have taken action in a British court to obtain relief and compensation in respect of an infringement of the Convention by the Crown or any other public authority. The bill would, on the face of it, have greatly strengthened the citizen's legal protection against the State or other public authority. He would have had a remedy in a national court against the State or other public authority in the event of an infringement, or a threat of infringement, of any of seventeen basic rights and freedoms which the United Kingdom Government by signing and ratifying the Convention and its 1st Protocol has guaranteed will be secured to everyone within the Kingdom without discrimination on any ground whatsoever.

* An amended version of the Eileen Illtyd David Lecture delivered at the University College of Swansea on 6th March 1986.

1. U.S. Declaration of Independence, Philadelphia, 4 July 1776.

2. Lord Broxbourne's Bill, infra $n 6$. 
The Convention is an international treaty which was drafted by the Council of Europe in the years immediately following the war when memories of Nazi oppression and inhumanity were fresh. It was seen by the member states of the Council of Europe as the minimum necessary to avoid a second holocaust. The United Kingdom was a member state and signed the Convention on the 4th November 1950. We later ratified it and it came into force in September 1953. It is a treaty binding on the United Kingdom in International Law. The United Kingdom has accepted ${ }^{3}$ the compulsory jurisdiction of the European Court of Human Rights which with the European Commission of Human Rights constitutes the legal machinery for the interpretation, application, and enforcement of the Convention. These two institutions have their seat at Strasbourg, which is also the headquarters of the Committee of Ministers which is the governing body of the Council of Europe.

The United Kingdom has also recognised the competence of the Commission to receive petitions from any person claiming to be the victim of an infringement by the United Kingdom of a right contained in the Convention. Fourteen human rights and fundamental freedoms are protected by the Convention itself; they are -

the right to life, freedom from inhuman or degrading punishment, freedom from forced labour, personal liberty, right to a fair and public trial, freedom from retrospective penalties, right to privacy, freedom of thought and religion, freedom of speech, right of peaceful assembly, freedom of association and to join trade unions, right to marry, and the enjoyment of these rights and freedoms without discrimination.

The first Protocol to the Convention, also ratified by the United Kingdom, has added a further three: the peaceful enjoyment of one's possessions, the right to education, and the freedom of elections. The Convention contains important provisions enabling member states to limit some of the freedoms secured by the Convention in the public interest in certain strictly defined circumstances and contains a power of derogation or suspension in time of emergency.

The Convention imposes the obligation upon signatory states to secure these rights and freedoms to everyone within their jurisdiction but does not, as a matter of positive obligation, require a contracting state to incorporate the Convention into its own domestic law. In fact all the states which have signed it - they include every member of the European Communities - have done so in one way or another, save only the United Kingdom. We have justified our decision not to do so upon the assumption that our law, as it stands, constitutes a full compliance with the Convention. We may have thought so in 1953; but can we really believe it today? The Court of Human Rights while recognising that there is no direct obligation upon contracting states to incorporate the Convention into the domestic law has said ${ }^{4}$ that by doing so a state does ensure that the intention of the

3. 1965 initially: subsequently reviewed.

4. Ireland v. U.K. Series A, No.25, 2 E.H.P.R. 25 (1976) para. 239. 
Convention is "faithfully reflected" in its laws: careful words, perhaps, but the meaning is clear. To the question - does British law faithfully reflect our duty under the Convention? - I shall give you an answer later.

Three attempts have been made to incorporate the Convention into our law, each upon the initiative of a private member of the House of Lords. The first two, by Lord Wade, failed: but he did secure the passage of a Bill of Rights through all its stages in the House of Lords only to fail in the Commons. He scored one significant victory. The House of Lords set up a Select Committee on a Bill of Rights, which reported in May 1978. ${ }^{5}$ The Committee were agreed in concluding that "if there is to be a Bill of Rights, it should be a Bill based on the European Convention." On the issue whether there should be a Bill the Committee was divided, six in favour and five against. They published a report, which is brief, clear, and, I suggest to anyone interested, compulsory reading.

The third attempt came nearest to success. ${ }^{6}$ Lord Broxbourne, a distinguished lawyer and in the past a Conservative cabinet minister, introduced the Bill in November 1985, and it passed all its stages in the Lords in the course of the session. As a private members bill it then went to the Commons, piloted by the Conservative Q.C., Sir Edward Gardiner, but it failed to pass second reading early in 1987, and accordingly fell. If it had been enacted could it have been protected against repeal or modification by a later Act of Parliament? The risk arises as much from inadvertent or accidental repeal as from deliberate policy.

The basis of the argument against incorporation is that under the British constitution the protection of our liberties is in the last resort political, not legal. The working principle of our constitution is the sovereignty of Parliament. ${ }^{7}$ It is not, therefore, possible to provide any effective legal safeguard either against Parliamentary mistake which results inadvertently in the repeal of a provision in the Bill of Rights, or against a Parliament irresponsibly determined upon repeal in whole or in part of the Bill of Rights. For Parliament exercises its sovereignty by its control of legislation. The Crown cannot legislate save with the advice and consent of Parliament: and there is no limit upon what Parliament can do by legislation. Further, Parliament is master of its own procedures: for instance, it cannot be compelled to treat certain Acts of Parliament, e.g. a Bill of Rights, as so fundamental that they cannot be repealed save by a specified majority or by referendum. And within Parliament one chamber, the elected House of Commons, is the dominant partner. The House of Lords has become an advisory and delaying chamber only. Its assent to legislation is no longer required if the Commons persist against the dissent of the Lords - save for one vital exception. The exception is that the Commons cannot prolong the life of a Parliament beyond the period of five years without the assent of the House of Lords. Lord Hailsham's

5. (176) H.L. 24 May 1978.

6. Human Rights and Fundamental Freedoms Bill.

7. Dicey, Introduction to the Study of the Constitution 10th ed. (1959), p.145. 
description ${ }^{8}$ of Parliamentary sovereignty as an elective dictatorship is true save for that exception. The hereditary, non-elected, appointed, chamber is, therefore, the ultimate safeguard of our liberties if they should be threated by a tyrannically minded majority in the House of Commons. Is this why some wish to see the House of Lords disappear, leaving us with single chamber government?

The right of our people to a general election at stated intervals and the power of a newly elected Parliament to repeal all or any of the legislation of its predecessors is a great protection against elective dictatorship; but it has one awkward consequence. It creates the impossibility of ensuring legal protection of our liberties against repeal or abrogation by Parliament. The real world, however, is not so dangerous as legal theory might suggest. If a Bill of Rights should be enacted, the political restraints against its repeal would be formidable indeed. I quote the words of wisdom and experience from the Select Committee's report (para. 16):

“... if a Bill of Rights were enacted, whatever form it took, there would in practice be the strongest political restraint against any acknowledged attempt to overturn it in a future Act. All the more would this be the case, if, as the Committee have concluded that it should, such a Bill took the form of an Act giving domestic effect to the European Convention. For in that event an acknowledged attempt to overturn the Bill of Rights would amount to an announcement that the Government was proposing to put us in breach of our international obligations."

I answer, therefore, the constitutional question thus. Legal protection, i.e. the protection of our basic rights and liberties enforced through our courts, is worthwhile: though it can only be achieved by Act of Parliament which itself is liable to repeal, the political forces militating against repeal are strong enough to ensure an acceptable degree of enduring legal protection. History suggests that we have little to fear. Our great constitutional enactments have survived the years notwithstanding they lack legal protection against repeal; Magna Carta 1215, the Act of Settlement and the Bill of Rights 1688/1689, and the Habeas Corpus Acts. An enacted modern Bill of Rights based upon the Convention could expect the same degree of political protection. Who would dare to repeal a statute based on an international obligation to secure the right to a fair trial or to freedom of speech?

\section{The heart of the matter}

I now declare my own position. I am an advocate of a modern British Bill of Rights: I agree with the unanimous opinion of the House of Lords Select Committee that if we are to have one it should be achieved by passing an Act of Parliament giving the Convention the force of law within the United Kingdom,

8. New Charter page 7: Pamphlet No. 430, Conservative Political Centre. 
and I supported Lord Broxbourne's Bill. There is a very practical but also fundamental advantage provided by a Bill of Rights based on the Convention. It would give the citizen aggrieved by an infringement of the Convention immediate access to a national court where he can obtain either relief from, or a remedy for, the infringement. At present, if, and we now know it is not really "if" but where so I say where our domestic law offers no remedy or protection, a citizen who has suffered an infringement faces formidable difficulties in enforcing his right: first, he must seek a remedy in the United Kingdom: secondly, and only when he can demonstrate that he has no remedy at home, he must go to Strasbourg to petition the Commission for Human Rights. If he establishes an admissible case the Commission may bring his case before the European Court of Human Rights. But he himself has no right to be heard by that court, though the Commission usually arranges its representation before the court so as to include representatives of the complainant petitioner.

"Justice delayed is justice denied" has been a principle of our law since Magna Carta. The existing arrangements for the enforcement in the United Kingdom of the Convention which I have outlined do amount to a denial of justice. They impose upon the aggrieved citizen difficulty, delay, and expense. And the delay is such that by the time a favourable result is obtained it is often too late to be an effective remedy. Take the case of $\mathrm{Mr}$ Golder. Mr Golder, while serving a sentence in a British prison, was refused permission to write to his solicitor to seek advice about defamation proceedings which he wished to bring against a prison officer. He was denied access to legal advice and to the courts. He petitioned the Commission who upheld his complaint that his Convention rights had been infringed and referred the case to the Court of Human Rights who also upheld the complaint. By the time the Court so ruled, Mr Golder had been out of prison for a long time. He had needed a remedy while he was in gaol: when it came, he no longer needed the remedy, for he was free and had been free for years. Needless to say, a Bill of Rights, had it been in force, would have given Mr Golder immediate access to a British court for a remedy when he needed it, i.e. while he was in gaol.

Mr Golder's case, however, does not provide a complete answer to the question: is a modern Bill of rights necessary? It is possible to urge that prisoners are a very limited class - too small to found a generalised criticism of our law. The traditionalists argue that the British combination of common law and statute law does in most cases effectually protect our basic rights and liberties without any need for incorporating into the law the Convention's positive declaration of human rights.

This argument was undoubtedly accepted, or its accuracy was at least assumed, by the British Government when it ratified the Convention. Indeed, the Government, had it taken the view that the Convention went further than our domestic law, would have considered itself bound to get passed through Parliament an Act bringing our law into line with the Convention before it ratified it. For this, in such circumstances, is accepted practice. 
The record unfortunately indicates that the Government's optimism was misplaced. Statistics, I recognise, are never the whole truth: but they can be significant danger signals. They can and sometimes should shatter complacency and cause one to re-examine a problem. The Strasbourg statistics covering as they do a large number of years administration of the Convention do suggest that we should re-examine the assumption that we do not need the Convention in our law.

When interpreting the figures which I shall give you, it is necessary to remember that every state which is party to the Convention other than the United Kingdom has by one mechanism or another effectually incorporated the Convention into its law: in some states, the Convention became part of their law upon ratification: in others, they had the benefit of a written constitution including a positive declaration of the rights and freedoms secured by the Convention. The Council of Europe has issued figures covering cases dealt with by the Court of Human Rights, the Committee of Ministers and the Commission over the period 1953 to the end of $1984 .^{9}$ The institutions dealt with a grand total of 205 arising within 13 contracting states: 57 violations were established, of which 18 (nearly one third) came from one state, the United Kingdom. The Council has also issued some figures for the year $1985 .^{10} 596$ applications by individuals alleging violation of the Convention were received from persons coming from 17 signatory states. 112 came from the United Kingdom - approximately one fifth of the total. These figures are, of course, less significant than those showing the number of violations established. But in each set of figures Britain returned the highest figures of any contracting state.

At the very least there must be a strong case for re-examining the adequacy of our law. Mr Golder is not the only complainant to have found that he had to make the long trek to Strasbourg. Immigrants, trade unionists, women, detainees for interrogation, are amongst those whose human rights have been held to have been violated in the United Kingdom without redress being available save by resort to Strasbourg. And all of you will have heard of the now famous thalidomide case in which the Sunday Times established at Strasbourg that the United Kingdom law as declared by the House of Lords, was a violation of the freedom of the press to impart information guaranteed by the Convention.

Experience suggests, therefore, that we should examine our law. If by incorporating the Convention into our law we can provide redress for infringements at home, we shall serve the cause of justice and at the same time avoid the embarrassment of an international court finding that our domestic law does not meet our international obligations.

When one looks at our domestic law we find that there is a weakness which arises from the very principle and history of the law. Having no written constitution spelling out constitutionally protected rights, we rely on the common law supplemented by statute to protect basic human rights. The common law is part of

9. Council of Europe, Strasbourg: 1985.

10. Council of Europe, Strasbourg: Survey of Activities in 1985. 
our unwritten constitution. Its principle is simple and, so far as it goes, marvellous, and never (I hope) to be abandoned, namely: you may do what you choose, unless there is a law against it. Freedom of speech, personal liberty, freedom of association, the right of assembly and demonstration depend upon the negative protection of the common law: there is no law against what you are doing: unless and until there is, you are, therefore, free to do it. As soon as, however, a positive right requires positive protection, the weakness of the common law is made plain. The right to privacy has no independent existence in English law: it is merely an incident of property. If you have no property, you have no privacy. The common law protects property, not privacy. Secondly, the common law cannot itself prevent discrimination between the sexes or on grounds of race, colour, or origin. Discrimination is today but was not always in the past, an ugly word: it means choice, selection or option. The common law, true to its principle, protects discrimination: the free man may choose what he does, with whom he associates, whom he employs unless there is a law against it. It follows that you can exercise your choice on grounds of sex or race unless there is a specific law against it: hence the necessity of recent legislation against sex inequality and racial discrimination. These are but two weaknesses in the common law's protection of positive rights. Another is, of course, the law relating to trade unions where much of the law's confusion has arisen from the failure of the law to recognise a positive right to strike. Indeed, the legal immunities of trade unions, which until recently have been a distinguishing, even a notorious, feature of our trade union law, would never have been necessary if there had been, as there is in other countries, a fully developed law of positive rights and duties in this field.

Our law needs to recognise that there are positive rights and obligations which a modern society has to protect and enforce. The common law's principle of freedom based on the absence of prohibition is not enough. It is the negative character of our law's approach to the problem of protecting and enforcing our basic rights and obligations which makes it necessary to introduce a Bill of Rights. And we have to hand, as the House of Lords Select Committee has recognised, the European Convention with its assertion of positive rights, freedoms and duties to which we are bound and which can without difficulty be incorporated into our law.

I therefore conclude that a Bill of Rights will be valuable even in our largely unwritten constitution: and that we would serve the cause of justice if we were to try once more to get Parliament to enact one.

11. A valuable summary will be found in Lester, [1984] Public Lan 46, at p.65. This article is an outstanding contribution to the literature. 